\title{
歩行解析への画像処理技術の応用に関する研究 APPLICATION OF DIGITAL IMAGE PROCESSING TECHNIQUES TO ANALYSIS OF PEDESTRIAN BEHAVIOR
}

\author{
过本 誠*, 志田弘二**, 建部謙 治*** \\ Makoto TSUIMMOTO, Kouji SHIDA and Kenji TATEBE
}

\begin{abstract}
The method which analyze the pedestrian movement quantitatively by using the digital image processing techniques is discussed in this paper.

The results are summarized as follows:

1) The method was developed to measure the position of pedestrians 30 times in every second automatically.

The main system of this method, using the fact that the hair is normally darker than the other parts, is to trace the position of hair automatically in the binary image which are made from the videotape recorded the movement of pedestrians.

2) Two experiments on walking in straight path and in L-shaped corner were performed.

By using the new method the data of both experiments were processed into the position, the velocity and accelerated velocity of pedestrian.

It was found to be effective to get the variation of the accelerated velocity of pedestrian for analyzing the movement.
\end{abstract}

Keywords : image processing technique, pedestrian behavior, accelerated velocity 画像処理技術, 歩行行動, 加速度

1.はじめに

人間の歩行を写真やビデオなどの画像として記録する ことは容易であるが，その画像から歩行の解析に必要な 数値データを一定の精度で自動的に収集することは容易 ではない。例えば, 歩行者頭部の位置の時間変化などは, $16 \mathrm{~mm}$ フィルムを 1 コマずつ計測者が目視で判定する ことが従来一般的であり，このような方法は作業量が膨 大であった。また判定が計測者に依存するため, 再現性 と精度に不安があっだ社。

そこで, 本報は，撮影したビデオ画像を「画像処理」 することで，上述のような歩行者の頭部の軌跡を自動的 にまた一定の精度で計測する方法を構築し, 二種類の歩 行実験・調查を対象に歩行の軌跡・速度, さらに加速度 を解析する。

\section{2. 画像処理の方法}

本報で用いた画像処理装置迆は，モニター上の画像
を縦 192 ドットメ横 256 ドットの画素に分割し，任意に 指定できる輝度の閾値で各ドット（画素）を白と黒に 2 値化した画像として出力する (写真一1)。さらに, 任意 の位置に設定したウインド内に存在する黒(もしくは白) のドット群の重心を計算し, 常にその重心にウインドの 中心を重ねることで目標物を自動追尾しながらその位置 を計測できる。位置計測の最小時間間隔はウインド 1 個 の場合は $1 / 30$ 秒である。この性質を利用して上方から 歩行を撮影した画像を処理すると, 頭髮部は身体の他の 部分や通路に比べて輝度が低いことが多く, 追尾してい る範囲に頭髮部より輝度の低い部分がなければ頭髮部の 動きを容易に計測できる。なお，画像处理装置から出力 される座標 (縦と横方向) の最小単位は, 装置の画像分 解能（縦 $192 \times$ 横 256 で単位はドット）の制約を受けて いる。装置のシステム構成を図一1に示す。

作業の省力化を具体的に示すと, 後述する $\mathrm{T}$ 字廊下 の歩行実験の場合では，延べ約 5 万回に及ぶ膨大な頭髪

\footnotetext{
* 名古屋大学工学部建築学科 助教授 $\cdot$ 工博

** 日本大学理工学部建築学科 助手. 工博

*** 愛知工業大学工学部建築学科 講師 . 工修
}

Assoc. Prof., Dept. of Architecture, Faculty of Engineering, Univ. of Nagoya, Dr. Eng.

Research Assoc., Dept. of Architecture, College of Science and Technology Univ. of Nihon, Dr. Eng.

Lecturer, Dept. of Architecture, Faculty of Engineering, Aichi Institute of Technology, M. Eng. 
部重心の計測とパソコンへのデータ転送の作業が 2 人 1 組で一日程度で完了した蛙。さうに，追尾を開始する 位置（ウインドを最初に置く位置）による計測値のばら つきは裆は, 街路直線歩行調査 (4 章) で実距離にして $25 \mathrm{~mm}$ 以内であり満足できる再現性と判断される。

\section{3. 座標変換の方法}

モニタ一画面上の座標を歩行者が位置する実際の通路 上の座標へ変換する方法を以下に説明する。座標変換そ のものは図学の基本理論に沿っており, 本報の目的とは 直接関係ないが, 既往の研究1)3゙ではほとんど説明され ていないこと, かつレンズの球面収差などの補正が必要 なためここで記述する。

本報では，座標変換のため以下の 4 点を考慮した。

(1)，スケール変換：モニター上の座標（単位ドット） を通路上の実寸 (単位 $\mathrm{mm}$ ) に変 換

（2） カメラ投影角：レンズの中心軸之通路面のなす角 が垂直でないことの補正

（3）レンズの球面収差の補正

（4）レンズ感光素子の繸横比が 1:1でないことの補 正

図一 2 に示すモニター上(画面(1) の座標 $\left(X_{1}, Y_{1}, Z_{1}\right)$ (ただし， $\left.Z_{1}=0\right)$ 加通路上（画面(5) 座標 $\left(X_{5}, Y_{5}\right.$, $Z_{5}$ ）(ただし， $Z_{5}$ は歩行者頭部の高さ）を得るため以下 の画面(2) (4)を仮定し，図学ならびに光学の基礎理論を 用いて変換した注5。

画面(2)：画面(1)にレンズ収差の補正とスケール変換 (ドットを $\mathrm{mm}$ に変換) を行った画面

画面(3)：レンズ中心軸に垂直でレンズ位置が原点となる 画面

画面(4)：レンズ中心軸と画面(5)（歩行者頭部の高さでの
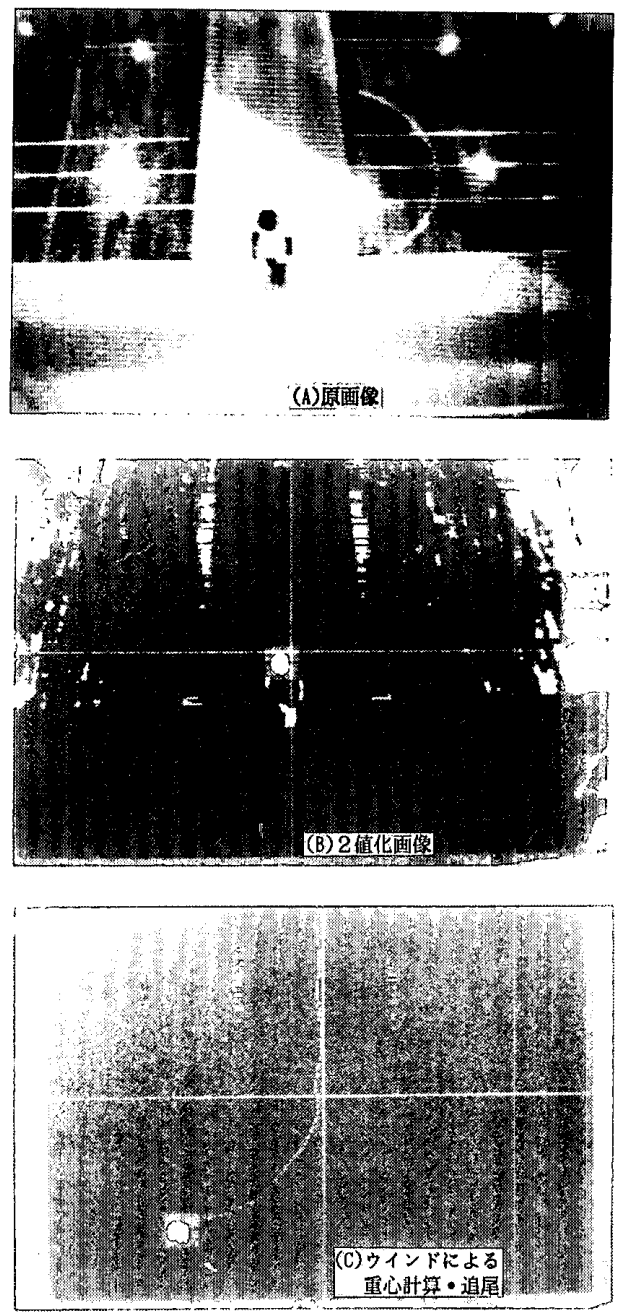

写真一 $1(A)(B)(C)$ 画像処理（2 値化）上重心計算 - 追尾

水平面) の交点まで画面(3)を平行移動した画面

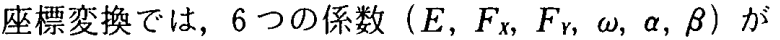
未知であり，これらを求めるためには画面(1)及び(5)上で 最低 6 点の座標が既知である必要がある。そこで，通路 上に基準点として合計 24 力所（直径 $140 \mathrm{~mm}$ の黒球を

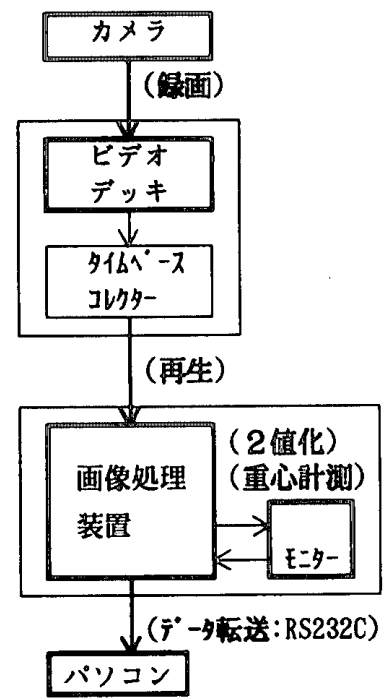

図-1 画像処理の概略フロ-(録画 からデー夕転送まで

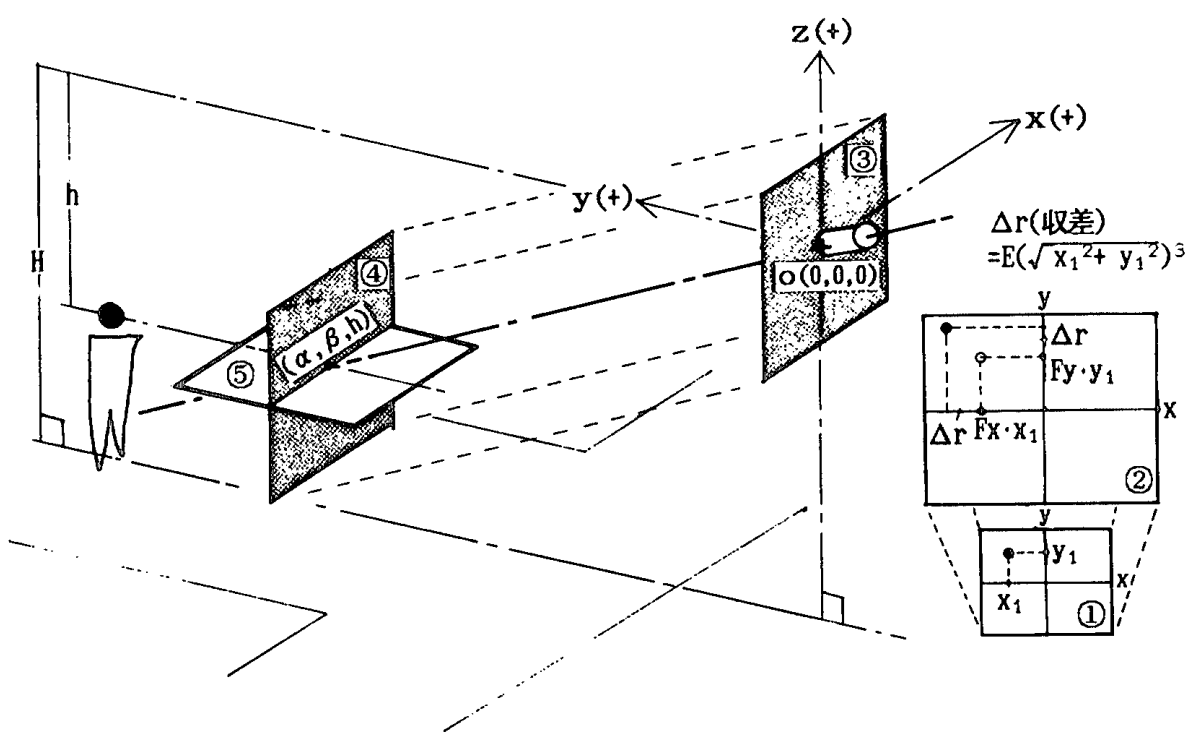

図-2 坐標変換の画面設定（模式図） 


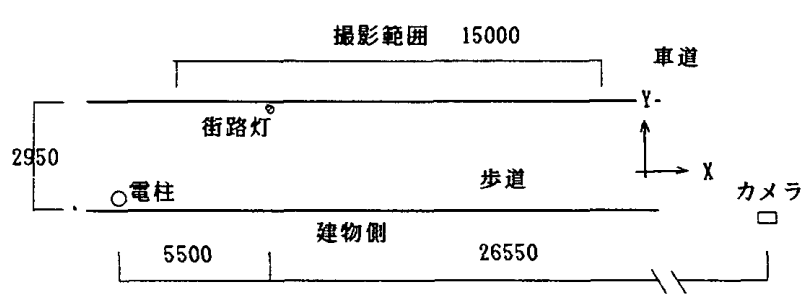

平面图

図-3(A) 街路直線歩行調查の平面・断面図
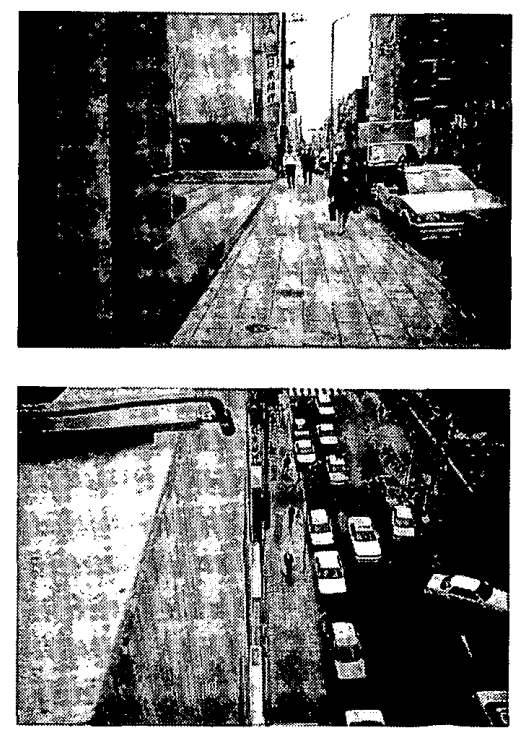

写真一2(A) 街路直線歩行調査（街路とカメラ設置の状況）

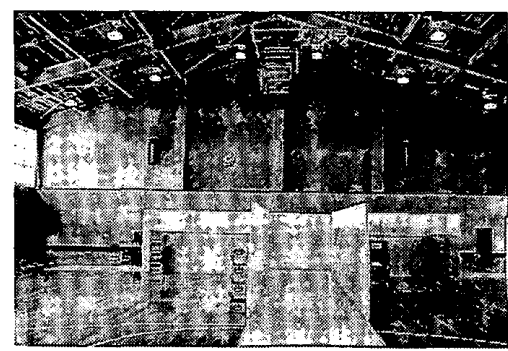

写真一2(B) $T$ 字廊下歩行実験（廊下とカメラ設置の状況）

通路面から一定の高さに設置）を実測して設置し録画し た。そして，これらの基準点の実測值と変換值（画面(5) 上)の誤差の 2 乗総和が最小になるように係数を定めた。

\section{4. 步行実験・調查の解析}

2 章 3 章に述べた画像処理の手法を利用して, 街路 での直線的な歩行の調査（以下, 街路直線歩行調査とす る, 図一3(A), 写真一 $2(A))$ ，ならびに体育館の一部 に $\mathrm{T}$ 字型の廊下を設営して実施した歩行実験（以下， $\mathrm{T}$ 字廊下歩行実験とする, 図一 $3(\mathrm{~B})$ ，写真一2(B)) に

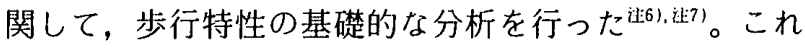
らの実験は別報で報告する回避行動 ${ }^{31,13\}, 14 \mid}$ の分析につな がるものである。
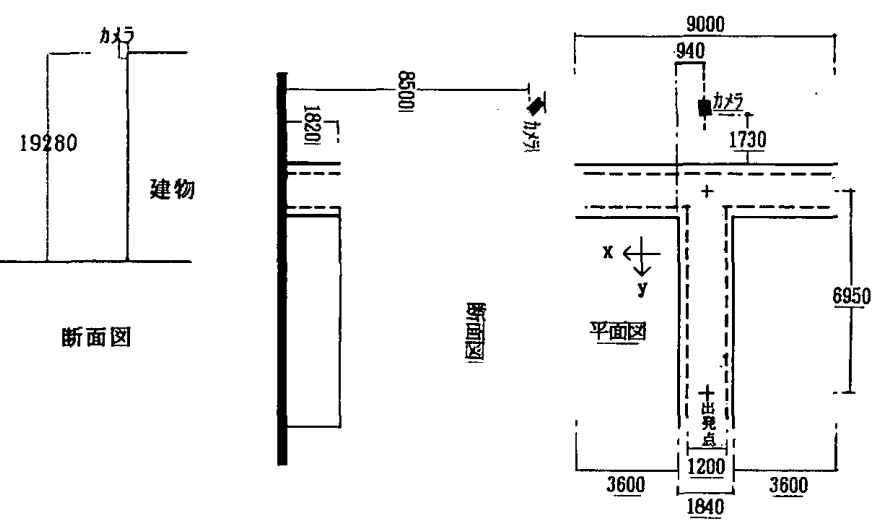

図一3(B) $\mathrm{T}$ 字廊下歩行実験の平面・断面図

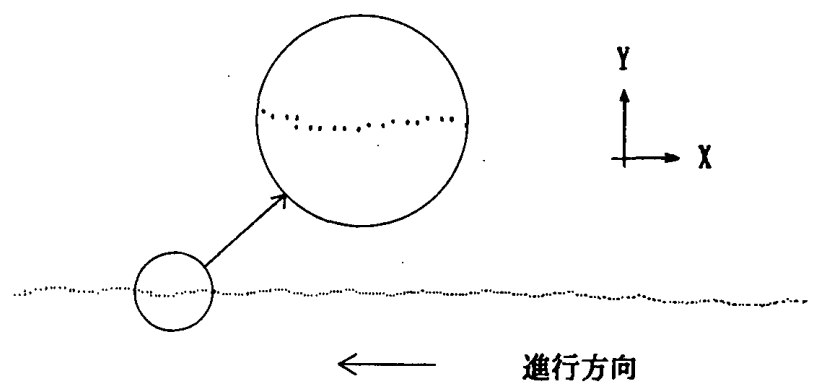

図一4 平滑化していない歩行軌跡（街路直線歩行の例）

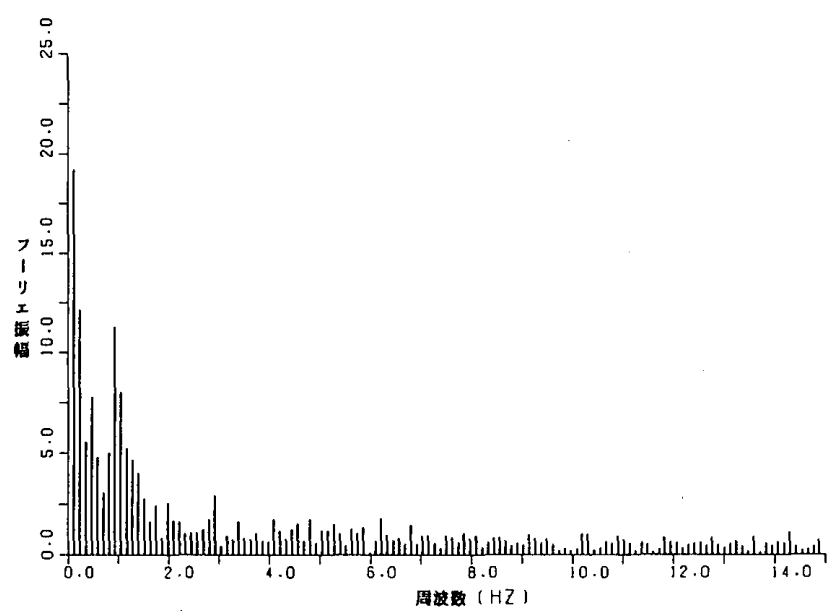

図一5 街路直線歩行における左右 $(Y)$ 方向のフーリエスペク トル

\section{1 歩行軌跡データの平滑化}

図一 4 は 3 章の処理をした街路直線歩行調查での軌跡 の計測例である。計測システムの画面分解能の影響を受 けて図のように軌跡は細かい振動を含んだデータとな る。このままでも軌跡の定性的な分析には支障がないが， 歩行の「曲がり」など動きの変化の判断材料となる加速 度などの定量的な分析には不適切である。そこで不要な 高周波数成分を除くために低域通過型のフィルター （ローパスフィルター）を用いてデータを平滑化するこ ととした。

図一 5 は図一 4 の歩行軌跡における進行方向と垂直な 座標值の周波数分析の例である注8)。分布に若干の個人 差はあるが $1.0 \mathrm{~Hz}$ 前後にピークがある。これは歩行に 
特有な横ゆれと判断されるのでこれを残し, $1.0 \mathrm{~Hz}$ 以 上の周波数をカットすることとした。そこでいくつかの デジタルフィルターを検討した結果, 以降の分析に妥当 な結果の得られたカットオフ周波数 $1.2 \mathrm{~Hz}$ の FIR 型 (Finite Impulse Response, 非巡回型) のローパスフィ ルターを用いて平滑化した。なお，このフィルターの種 類については目的に応じて選択すべきものと考えられ る染9!。

\section{2 平滑後の軌跡之速度 ·加速度}

平滑後のデータを用い, 街路直線歩行と $\mathrm{T}$ 字廊下歩 行の歩行軌跡, 歩行速度, 加速度这101について分析する。 図一6 と図一7に典型的な測定例を示した。また，図一8 と図一9は各位置での加速度をべクトル表示したもので
ある。

直線的に歩行する場合 (街路直線歩行調查), 図一6 の進行方向に垂直な方向の加速度 $\left(A_{y}\right)$ 之図一8 の加速 度ベクトルの変化から分かるように, 歩行者は $1.0 \mathrm{~Hz}$ 前後で規則的に左右に横ゆれし，加速・減速を繰り返し ながら進行する。これは両脚の着床, 蹴り出しの繰り返 し ${ }^{12)}$ に対応するものである。測定例 (37 名) の範囲では, 進路からの頭部のズレ（測定開始点を原点とし垂直な方 向の位置座標）は $7 \mathrm{~cm}$ 加 $83 \mathrm{~cm}$ の範囲，また最大加 速度 $\left(A_{y} \cdot \max \right)$ は 0.69 2.24 m/ $\mathrm{sec}^{2}$ の範囲である（図 一10)。ただし，この測定のような場合，歩行者は必ず しも直線的に進行するわけではなく，わずかな蛇行を見 せるものが多い。
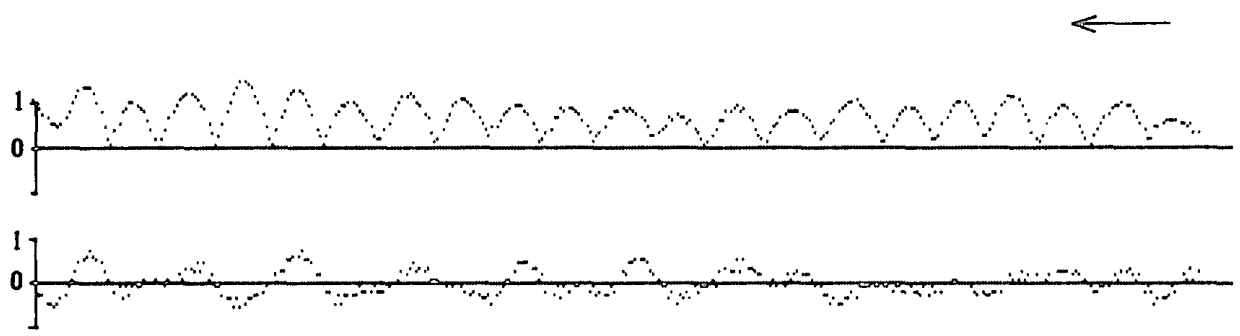

$A\left(m / \sec ^{2}\right)$ $A \max \quad 1.45$

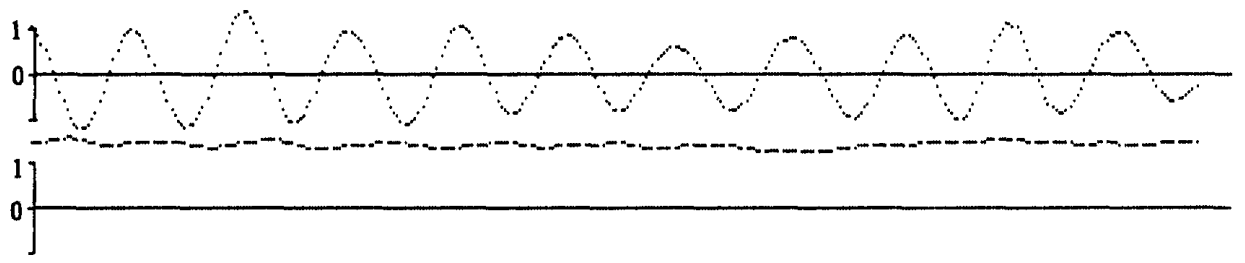
$A x\left(m / \sec ^{3}\right)$ Ax. $\max 0.54$

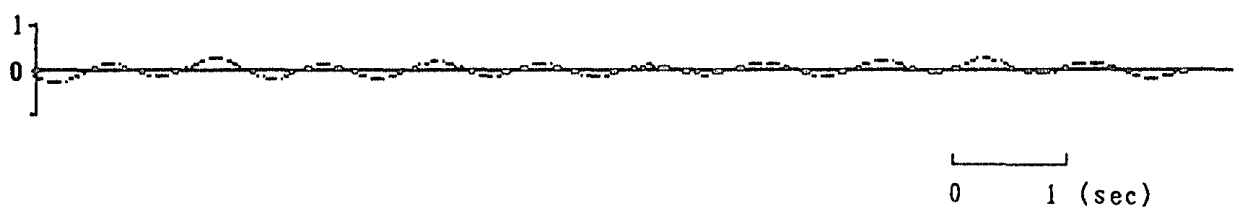

Ay $\left(\pi / \sec ^{2}\right)$ Ay. $\max 1.38$

$V x(m / s e c)$

$\operatorname{Vy}(\mathrm{m} / \mathrm{sec})$

図-6 街路直線歩行の速度・加速度の変化（カットオフ周波数 $1.2 \mathrm{~Hz}$, 図一 4 之同一の歩行者）

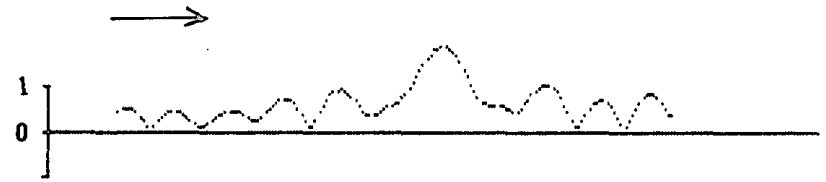

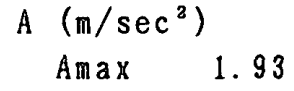

$A x\left(m / \sec ^{2}\right)$

Ax. $\max 1.31$
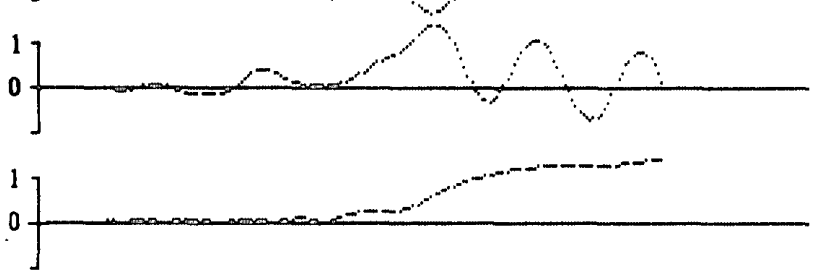

$\operatorname{Ay}\left(\pi / \sec ^{2}\right)$

Ay. 而ax 1.42

$V x(\pi / s e c)$

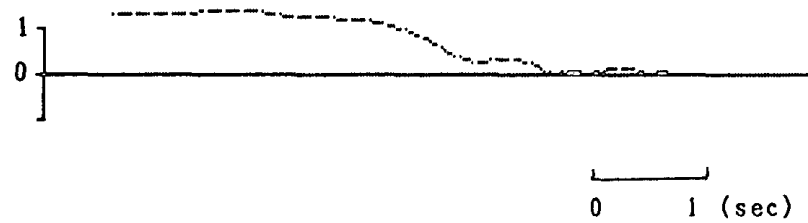
$V_{y}(\pi / \sec )$
凡例

A : 加速度 Anax : 最大加速度 $\mathrm{Ax} \quad: \mathrm{x}$ 方向の加速度 Ax. max : X方向の最大加速度 Ay : $Y$ 方向の加速度 Ay. max:Y方向の最大加速度 $V \mathrm{~K}: \mathrm{:} X$ 方向の速度 Vy : Y方向の速度

図一7 $\mathrm{T}$ 字廊下歩行の速度・加速度の変化（カットオフ周波数 $1.2 \mathrm{~Hz}$ ) 


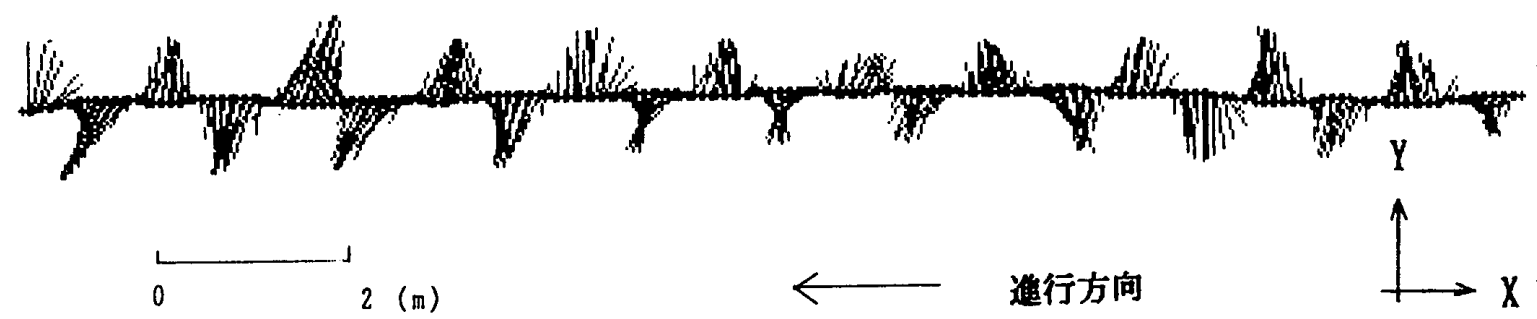

図-8 街路直線歩行の歩行軌跡と各点での加速度 (カットオフ周波数 $1.2 \mathrm{~Hz}$, 図一 4 と同一の歩行者)

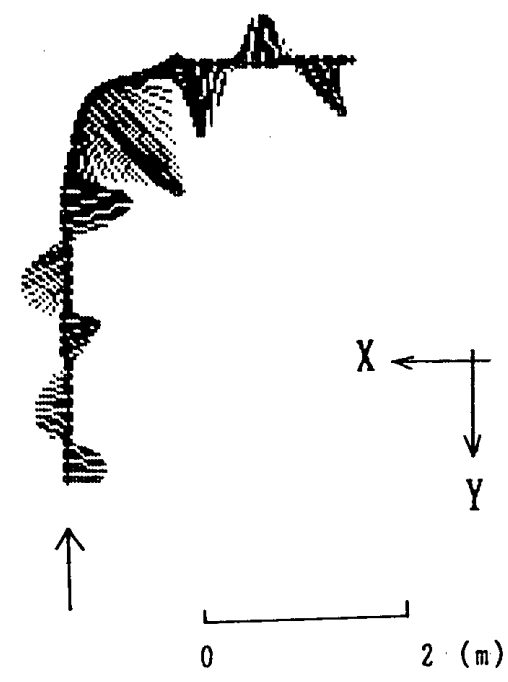

图一9 $\mathrm{T}$ 字廊下歩行の歩行軌跡と各点での加速度

(カットオフ周波数 $1.2 \mathrm{~Hz}$, 図一7 と同一の歩行者)
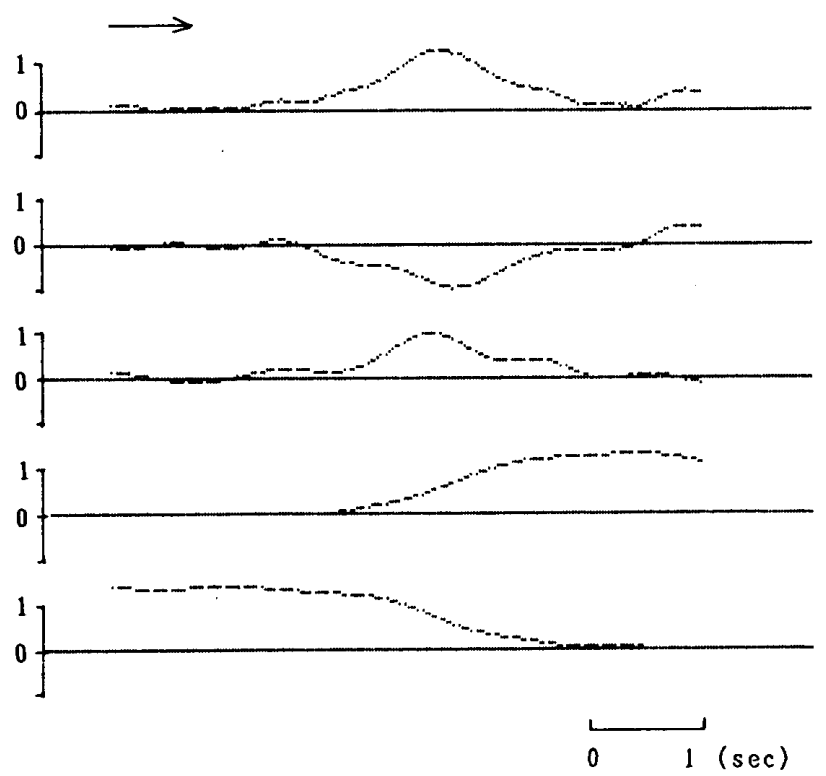

图一11 $\mathrm{T}$ 字廊下歩行の速度・加速度の変化

(カットオフ周波数 $0.7 \mathrm{~Hz}$, 図一7 と同一の歩行者)

一方， T 字嫏下の幅員が曲がり方に及ぼす影響を検 討しようとすれば，横ゆれなどを除いた歩行の全体的な 動きをとらえた方が有効であり，4.1で述べたように， 分析の目的に応じてカットオフ周波数の選択を行えば良 い。例えば横ゆれを除くような平滑化（カットオフ周波 数 $0.7 \mathrm{~Hz}$ ) を行うと図一11 と図一12 に示すようになる。
相対度数

$\begin{array}{ll}\text { Ay.max }\left(\mathrm{m} / \mathrm{sec}^{2}\right) \\ 0.50 \leqq & <0.75 \\ 0.75 & 1.00 \\ 1.00 & 1.25 \\ 1.25 & 1.50 \\ 1.50 & 1.75 \\ 1.75 & 2.00 \\ 2.00 & 2.25\end{array}$

25

$50 \quad(\%)$

図一10 街路直線歩行における左右 $(Y)$ 方向の最大加速度（個 人) の度数分布

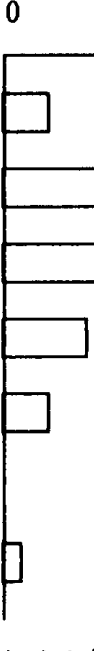

1

剆定人数 37 名
$A\left(m / \sec ^{2}\right)$
$\operatorname{Amax} \quad 1.35$

$A x\left(\pi / \sec ^{2}\right)$

Ax. $\max 0.97$

Ay $\left(m / \sec ^{2}\right)$

Ay.max 1.01

$V x(m / s e c)$

$V y(m / s e c)$

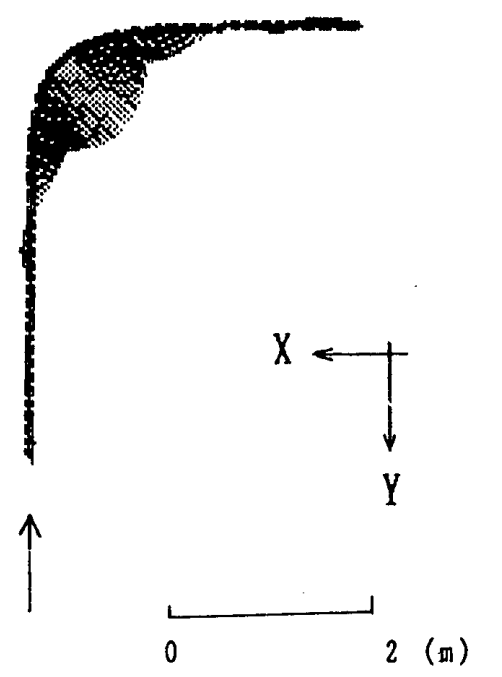

図-12 T 字廊下歩行の歩行軌跡亡加速度 (カットオフ周波数 $0.7 \mathrm{~Hz}$, 図一7 と同一の歩行者)

この場合の分析結果については文献 10), 文献 11）にま とめている。

$\mathrm{T}$ 字廊下歩行の測定例（幅 $1.84 \mathrm{~m}$, 右回り 38 名) の 場合，図一9に示す例のように，図一8同様に直線部で 進行方向の左右に規則的に現れる加速度が曲線部では曲 がるための加速度が大きいために曲がり方向だけになる 
傾向がある（全歩行者中約 $60 \%$ ）。またその絶対値は街 路直線歩行調育に比べて約 1.3 倍となる。

\section{5.おわりに}

画像処理技術を応用して，歩行における頭部の軌跡を 自動的に一定の精度で計测する方法を構築した。また， これに基づいて二種穎の歩行実験・調㚗を対象にして歩 行の軌跡・速度・加速度について解析した。

従来, ビデオ画像などの視覚情報を定量的に処理する 際に人間の主観に頼っていた部分を客観的・自動的に処 理する方法の確立は，その応用する分野も広く新たな解 析手法の一つになり得ると考える。

最後に, フーリ工変換については名古屋大学河野 守 講師と愛知工業大学加藤厚生教授に貴重な御助言を賜っ た。また，この研究を遂行するにあたり田中春彦氏（名 古屋大学卒論生, 現在戸田建設)，村上秀隆氏（同愛知 県庁)，ならびに愛知工業大学の卒論生の多大なる御協 力を得た。記して謝意を表します。

注

1） $16 \mathrm{~mm}$ フィルムやビデオ画像を用いた既往の歩行研究と して，文献1) 〜文献 3）などがあるが，いずれも計测は 目視に頼っている。

2）・画像処理装置：(株) 朋栄 IV540

。録画と再生の機器

ビデオデッキ：一般的なVHS のビデオデッキ

ビデオカメラ：撮像素子インターライン転送方式 CCD 力メラ, 有効画素数水平 $510 \times$ 垂直 492 , 毎秒像数 30 枚, レンズ：焦点距離 $8 \mathrm{~mm}$, 皎り $\mathrm{F} 1.4 \sim \mathrm{F} 360$, 自動絞り調 節範囲 30 100, 000lux

3）目視計測の場合では手動でのコマ送り操作ならびに画面 上の目標物へのライトペン指示などの操作の絽り返しが 伴うため，筆者らの過去の経験を基にすると少なくとも 十倍以上の作業量を要する。

4）いわゆる計測機器に内在する誤差であり，注 7)でいう 測定誤差とは異なるものである。

5）面面(1)一画面(2)：収差補正とスケール変換 $X_{2}=\left(1+E \cdot\left(\sqrt{X_{1}^{2}+Y_{1}^{2}}\right)^{2}\right) \times(h / \gamma) \times F_{x} \times X_{1}$ $Y_{2}=\left(1+E \cdot\left(\sqrt{X_{1}^{2}+Y_{1}^{2}}\right)^{2}\right) \times(h / \gamma) \times F_{y} \times Y_{1}$ $Z_{2}=Z_{1}=0$

$E$ : レンズの球面収差の補正係数

$\left(1+E \cdot\left(\sqrt{X_{1}^{2}+Y_{1}^{2}}\right)^{2}\right)$ は，レンズ収差を補正するため $X_{1}$, $Y_{1}$ に掛ける倍率である。レンズ中心軸近傍のガウス領域 から発してレンズを通った光は入射角 $\theta \approx 0$ であるから， $\sin \theta=\theta$

と近似できる。しかし，ガウス領域以外ではザイデルの 五収差の理論を用いてテーラー展開の第 2 項までとり, $\sin \theta=\theta-(1 / 3) \theta^{2}$

と近似できる範囲では，収差 $\Delta r$ は， $\Delta r=e \cdot \theta^{3} \quad$ (ただし, $e$ は収差の比例定数）

で求められる。レンズから像平面までの距離を $L$ ，レン ズ中心軸と像平面との交点 0 と $\left(X_{1}, Y_{1}\right)$ との距離を $\gamma^{\prime}$, $r=\Delta r+r^{\prime}$, 屈折角を $\theta^{\prime}$ とすると, $\theta \approx \theta^{\prime}$ よって $\theta \approx\left(r^{\prime} / L\right)$

と近似して,

$\Delta r=E \cdot\left(\sqrt{X_{1}^{2}+Y_{1}^{2}}\right)^{3}$

$E$ は比例定数 $=e / L^{3}$

よって,

$$
r / r^{\prime}=\Delta r / r^{\prime}+1=1+E \cdot\left(\sqrt{X_{1}^{2}+Y_{1}^{2}}\right)^{2}
$$

が得られる文)。

$F_{X}, F_{Y}:$ モニター上の $X$ 方向と $Y$ 方向のスケール変換 係数

$h:$ 歩行者頭部の $Z$ 軸座標 $=H+(K-(c / 2))$

$K$ : 歩行者身長 (自己申告值あるいは推定)

$c$ : 頭高（既存文献（文 5 , 文 6) から一定と判断し, 平均值 $250 \mathrm{~mm}$ を用いた。）

$H$ : 通路面の $Z$ 軸座標

$\gamma$ : 基準点 (3 章参照) $\sigma Z$ 軸座標

$h / \gamma$ : 基準点を基にして求めた各係数を歩行者身長に 合わせて補正する係数

なお， $Z$ 軸座標 $h, H, \gamma$ はレンズ位置を原点として与 える(いずれも符号はマイナス)

画面(2) $\rightarrow$ 画面(3)

画面(1) (モニタ一上) の座標と通路上の座標を結び付 けるため，レンズの位置を原点とする $Z, X, Y$ 軸まわ りの回転を行う文7)。行列式は下記となる。

$$
\left(\begin{array}{l}
X_{3} \\
Y_{3} \\
Z_{3}
\end{array}\right)=\left(\begin{array}{ll}
\cos \psi \cos \omega & -\cos \psi \sin \omega \\
+\sin \phi \sin \psi \sin \omega & -\sin \phi \sin \psi \sin \omega \\
\cos \phi \sin \omega & \cos \phi \cos \omega \\
\sin \psi \cos \omega & -\sin \psi \sin \omega \\
-\cos \psi \sin \phi \sin \omega & +\cos \psi \sin \phi \sin \omega
\end{array}\right.
$$

$\left.\begin{array}{l}\sin \phi \cos \phi \\ \sin \phi \\ \cos \phi \cos \phi\end{array}\right) \cdot\left(\begin{array}{l}X_{2} \\ Y_{2} \\ Z_{2}\end{array}\right)$

$\phi: X$ 軸まわりの回転角 $=\sin ^{-1}\left(\beta /\left(\sqrt{\alpha^{2}+\beta^{2}+\gamma^{2}}\right)\right)$

$\psi: Y$ 軸まわりの回転角 $=\sin ^{-1}\left(\alpha /\left(\sqrt{a^{2}+\beta^{2}+\gamma^{2}}\right)\right)$

$\omega$ :レンズ中心軸まわりの回転角

$X$ 軸, $Y$ 軸まわりの回転角はレンズの中心軸の方向べ クトル $(\alpha, \beta, \gamma)$ のみで決まるが， $Z$ 朝まわりの回転角 はレンズの中心軸まわりの回転も含むので方向ベクトル だけではなくレンズの設置方向によっても変化する。 画面(3) $\rightarrow$ 画面(4)

$$
\left(\begin{array}{l}
X_{4} \\
Y_{4} \\
Z_{4}
\end{array}\right)=\left(\begin{array}{c}
X_{3} \\
Y_{3} \\
Z_{3}
\end{array}\right)+(\mathrm{h} / \gamma) \cdot\left(\begin{array}{c}
\alpha \\
\beta \\
\gamma
\end{array}\right)
$$

$(\alpha, \beta, \gamma)$ : レンズ中心軸と基準点高さでの水平面との交 点の $X, Y, Z$ 座標

画面(4) $\rightarrow$ 画面(5)

$$
\begin{aligned}
& X_{5}=\left(\mathrm{h} / Z_{4}\right) \times X_{4} \\
& Y_{5}=\left(\mathrm{h} / Z_{4}\right) \times X_{4} \\
& Z_{5}=Z_{4}
\end{aligned}
$$

6) 実験・調查の方法の概略

（1）街路直線歩行調査では，ビジネス街の歩道（有効 幅員約 $2.9 \mathrm{~m}$ ) で撮影に気付いていない一般の人たちが 歩行する様子を頭上 $19.3 \mathrm{~m}$ からビデオカメラで撮影し た。被験者は単独で直線歩行を行ったと判断した成人男 子 37 名である。基準点は 24 点（高さ $1.68 \mathrm{~m}$ ) を設定し た。 
注表＼cjkstart変換係数の収束計算結果

\begin{tabular}{|c|c|c|c|c|c|c|c|}
\hline & \multicolumn{2}{|c|}{$\begin{array}{l}\text { スケール变換 } \\
\text { の保数 }\end{array}$} & \multirow{2}{*}{$\begin{array}{l}\text { 球面収着 } \\
\text { 㭪正の } \\
\text { 此俰定数 } \\
\mathrm{E}\end{array}$} & \multirow{2}{*}{ 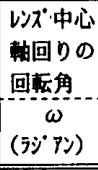 } & \multicolumn{2}{|c|}{$\begin{array}{l}\text { いズ 中心响と } \\
\text { 基準点高さ } \gamma \text { ての } \\
\text { 水平面との交点 } \\
\end{array}$} \\
\hline & & & $\mathrm{F}_{\mathrm{Y}}$ & & & 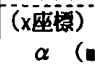 & 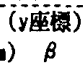 \\
\hline $\begin{array}{c}\text { T字 } \\
\text { 郎下 }\end{array}$ & & & $\begin{array}{l}26.04 \\
25.96\end{array}$ & & & $\begin{array}{r}62 \\
100\end{array}$ & $\begin{array}{l}4401 \\
4396\end{array}$ \\
\hline 街 & 行 & 37.50 & 38.30 & $1.0 \times 10^{-10}$ & -0.0250 & -21850 & $176 x$ \\
\hline
\end{tabular}

（2） T 字廊下歩行実験では，仮設した廊下を単独歩行 する被験者が L 字に曲がる様子を頭上 $8.5 \mathrm{~m}$ からビデオ カメラで撮影した。廊下内法幅を $1.20 \mathrm{~m}$ と $1.84 \mathrm{~m}$ の 2 種類とし，両側に高さ $1.82 \mathrm{~m}$ で壁を設け天井は設置して いない。被験者は男子大学生で，年龆・身長・利き腕を 実験前にアンケート調查した。被験者数は $1.84 \mathrm{~m}$ 幅が 38 名， $1.20 \mathrm{~m}$ 幅が 40 名である。基準点は 48 点（24 力 所各々に対し高さ $1.65 \mathrm{~m}$ と $1.75 \mathrm{~m}$ の二種類）を設定し た。

7) 座標変換の係数決定之誤差の検討

二種類の歩行奏験・調查の係数を 3 章の座標変換の方 法を用いて決定した結果が注表である。

基準点ごとの誤差の平均（誤差の 2 乗総和を基準点数 で除した値の平方根）ならびに誤差の最大は, 街路直線 歩行調查の場合は, 平均 $57 \mathrm{~mm}$ (最大 $104 \mathrm{~mm}$ ), また”T 字廊下歩行実験の場合は, 廊下幅 $1.84 \mathrm{~m}$ では平均 14 $\mathrm{mm}$ (最大 $28 \mathrm{~mm}$ ), 廊下幅 $1.20 \mathrm{~m}$ では平均 $16 \mathrm{~mm}$ (最 大 $31 \mathrm{~mm}$ ) である。

8）高速フーリエ変換（FFT）で周波数分析をした文8)。各サ ンプルのデータ総数は 300 点から 400 点（計測時間がお よそ 10 秒) であるため，計算で使用するデー夕数は 256 $\left(=2^{8}\right)$ 点とした。また，進行方向とこれに垂直な方向 の成分に分け，時刻 $i$ におけるデー夕を差分により求め た。さらに幾何平均を計算しこれとの差を個々のデータ として解析を行った。

分解能は $30 / 256(=0.117) \mathrm{Hz}$ 以上 $15 \mathrm{~Hz}$ 以下である。 なお, 計算は名古屋大学大型計算機センターの FFTR を 使用した。

9）文献 9) の pp. 55〜90なよ゙を参照

本報では，カットオフ周波数は $1.2 \mathrm{~Hz}$ ，空関数は八ミ ング空, 応答時間は $25 / 30$ (秒) とした。また, 変位が $X$ 方向と $\mathrm{Y}$ 方向の 2 個であるのでフィルターを通した時 に位相のズレが問題となるが，ここでは直線位相性を実 現できるFIR 型のフィルターを用いて位相差を0にして いる。
10) 時刻 $i(i=n \cdot \Delta t)$ における速度 $V(i)$ と加速度 $A(i)$

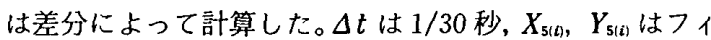
ルターを通した座標を用いている。

$$
\begin{aligned}
& V_{X}(i)=\left(X_{5(i+1)}-X_{5(i-1)}\right) / 2 \Delta t: X \text { 方向 } \\
& V_{Y}(i)=\left(Y_{5(i+1)}-Y_{5(i-1)}\right) / 2 \Delta t: Y \text { 方向 } \\
& V(i)=\sqrt{V_{X}(i)^{2}+V_{X}(i)^{2}} \\
& A_{X}(i)=\left(X_{5(i+1)}-2 X_{5(i)}+X_{5(i-1)}\right) /(\Delta t)^{2}: X \text { 方向 } \\
& A_{Y}(i)=\left(Y_{5(i+1)}-2 Y_{5(i)}+Y_{5(i-1)}\right) /(\Delta t)^{2}: Y \text { 方向 } \\
& A(i)=\sqrt{A_{X}(i)^{2}+A_{Y}(i)^{2}}
\end{aligned}
$$

\section{参考文献}

1）中祐一郎：交差流動の構造-鉄道駅における旅客の交錯流 動に関する研究(1), 日本建築学会論文報告集, 第 258 号, pp. 93 102，1977 年 8 月

2）加藤邦夫ほか：群集対向流動の解析, 日本建築学会論文 報告集，第 289 号，pp. 119 129，1980 年 3 月

3）建部謙治, 中島 一: 静止した障害物に対する単独歩行 者の回避行動, 歩行者の回避行動に関する研究 (I ), 日 本建築学会計画系論文報告集，第 418 号, pp. 51 57, 1990 年 12 月

4） 久保田広：応用光学, 岩波全書

5）小原二郎ほか：建築室内人間工学，鹿島出版会

6）日本建築学会編：建築設計資料集成 $3 \cdot$ 単位空間 I, 丸 善

7) 矢野健太郎ほか：線形代数，裳華房

8）建部謙治, 辻本 誠, 志田弘二：歩行のスペクトル解析, 日本インテリア学会研究発表梗概集 No. 3, 1991 年 11 月

9) 三谷政昭：デジタルフィルターデザイン，昭晃堂

10）志田弘二, 计本 誠, 田中春彦ほか：画像処理を利用し た建築空間内の人間行動の研究一T 字型廊下での歩行実 験, 日本建築学会東海支部研究報告, 1989 年 2 月

11）志田弘二, 辻本 誠ほか：画像処理を利用した建築空間 内の歩行解析とシミュレーション, 日本建築学会大会学 術講演梗概集 E, 1989 年 10 月

12）阿久津邦男著：歩行の科学, 不昧堂出版，1975 年 5 月

13）建部謙治, 过本 誠, 志田弘二, 中島 - : 画像処理を 利用した回避行動開始点の判定方法, 日本建築学会東海 支部研究報告, 1991 年 2 月

14）建部謙治, 辻本 誠, 志田弘二, 中島 - : 画像処理を 利用した歩行者の回避行動に関する研究一回避行動開始 点の判定方法一, 日本建築学会大会学術講演梗概集 $\mathrm{E}$, pp. $691 \sim 692,1991$ 年 9 月

(1991 年 12 月 25 日原稿受理, 1992 年 4 月 8 日採用決定) 